\title{
Correction to: An environmental risk assessment for a DDX-contaminated agricultural area in Turkey: soil vs. plant or human vs. animal
}

\section{Mahmut Kemal Korucu $^{1}$ (D) P Pinar Sevim Elibol ${ }^{2} \cdot$ Mehmet Isleyen $^{1}$}

Published online: 15 May 2021

(C) Springer-Verlag GmbH Germany, part of Springer Nature 2021

\section{Correction to: Environmental Science and Pollution Research} https://doi.org/10.1007/s11356-021-14154-4

The correct image of Fig. 5 is shown in this paper.

Fig. $5 \mathrm{HQ}_{\text {eco }}$ values for soil samples (unitless)

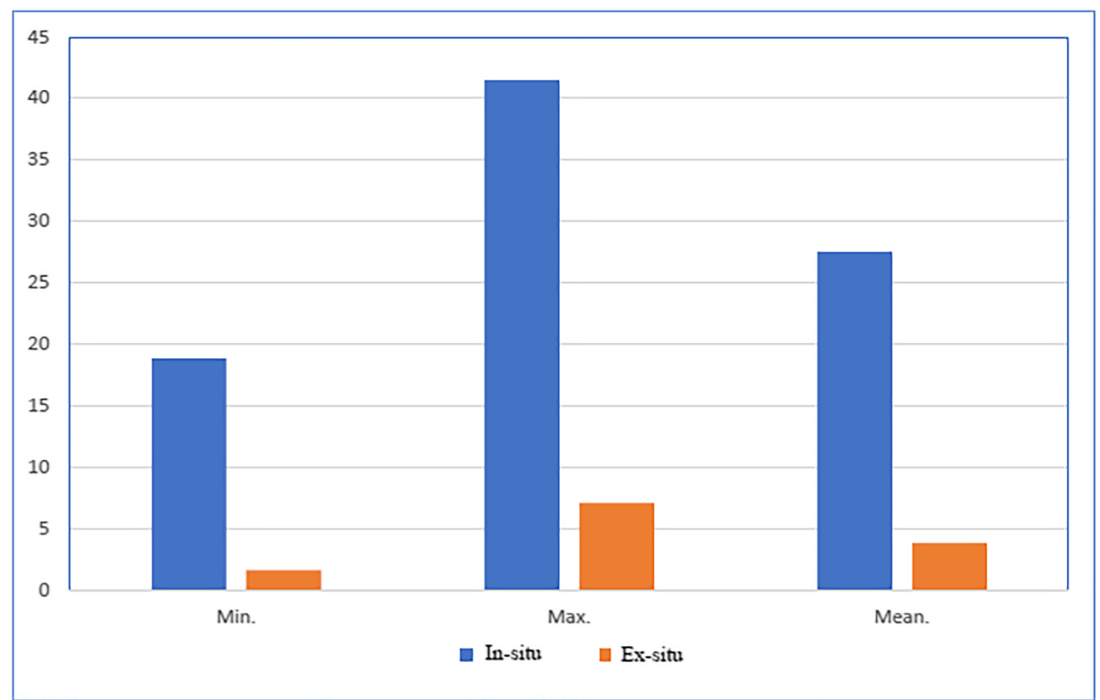

Publisher's note Springer Nature remains neutral with regard to jurisdictional claims in published maps and institutional affiliations.

The online version of the original article can be found at https://oi.org/ 10.1007/s11356-021-14154-4

Mahmut Kemal Korucu kemal.korucu@btu.edu.tr

1 Department of Environmental Engineering, Bursa Technical University, Mimar Sinan Campus, Mimar Sinan Boulevard, Eflak Street, 16310 Bursa, Turkey

2 Department of Environmental Engineering, Duzce University, Duzce, Turkey 